\title{
A Transformation of Islamic Law in Legislation of Domestic Violence (PDKRT) Law in Indonesia
}

\author{
Liky Faizal
}

\begin{abstract}
A Transformation of Islamic Law in Legislation of Domestic Violence (PDKRT) Law in Indonesia. This article aims to study the transformation of Islamic Sharia values in the foundation of the law legislation in Indonesia. This study is legalnormative in which, in its analyzing phases, it uses both qualitative techniques of primary and secondary legal materials. The findings of this study indicate that the Islamic Shari'a values have been actualized in the laws and regulations in the elimination of domestic violence in Indonesia. Transformation of Islamic Sharia values is conducted through two approaches, namely through the principles of the content of legislation, and actualization through the material legislation.
\end{abstract}

Keywords: transformation, religious values, domestic violence

\begin{abstract}
Abstrak: Transformasi Hukum Islam dalam Undang-Undang tentang Kekerasan dalam Rumab Tangga (PDKRT) di Indonesia. Artikel ini bertujuan untuk mempelajari transformasi nilai-nilai syariah Islam dalam landasan undang-undang hukum di Indonesia. Penelitian ini adalah normatif hukum, di mana dalam fase analisisnya, menggunakan teknik kualitatif bahan hukum primer dan sekunder. Temuan penelitian ini menunjukkan bahwa nilai-nilai syariah Islam telah diaktualisasikan dalam undangundang dan peraturan mengenai penghapusan kekerasan dalam rumah tangga di Indonesia. Transformasi nilai-nilai syariah Islam dilakukan melalui dua pendekatan, yaitu melalui prinsip-prinsip isi undang-undang, dan aktualisasi melalui materi undang-undang.
\end{abstract}

Kata Kunci: transformasi, nilai-nilai agama, kekerasan rumah tangga

Faculty of Sharia Islamic State University Raden Intan Lampung

Jl. H. Endro Suratmin, Sukarame, Bandar Lampung

E-mail: likyfaizal@gmail.com 


\section{Introduction}

Marriage as a legal act between husband and wife is not only for the realization of worship to God, but also gives rise to civil legal effect between the two. However, since the purpose of marriage is so precious that is to build a happy family, eternal, immortal based on God's command, it is necessary to set the rights and obligations between husband and the wife. If their rights and obligations are fulfilled, then the desire of households with a foundation of love and affection will come true. ${ }^{1}$

Violence is an act committed by a person or a person who plays a strong (or middle feel strong) against a person or a person who plays a weaker (or being deemed to be in a weakened state), using strengthphysical and non-physical- thing that is superior, with the intent to cause a sense of anguish in the violence objects. Another opinion says that violence is an attack or invasion (assault) against the physical and psychological integrity of a person's mental. ${ }^{2}$

Violence in the household (domestic violence) is a type of crime that received less attention. Violence at home usually involves perpetrators and victims among family members in the household, whereas any forms of violence may include physical violence and verbal violence (threats of

${ }^{1}$ Ahmad Rofiq, Hukum Islam di Indonesia(Jakarta: RajaGrafindo Persada, 1998), p. 181.

${ }^{2}$ Mansour Fakih, Menggeser Konsepsi Gender dan Transformasi Sosial (Yogyakarta: Pustaka Pelajar, 1996), p. 12. See also Estu Rakhmi Fanani, "Undang-Undang Nomor 23 Tahun 2004 Tentang Kekerasan dalam Rumah Tangga, Antara Terobosan Hukum dan Fakta Pelaksanaannya”, Jurnal Legislasi Indonesia 5, No. 3, (September 2008): p. 2-171. Hamidah Abdurrachman. "Perlindungan Hukum Terhadap Korban Kekerasan dalam Rumah Tangga dalam Putusan Pengadilan Negeri Sebagai Implementasi Hak-Hak Korban.” Jurnal Hukum Ius Quia Iustum 17, no. 3 (2010): p. 475-491. Rochmat Wahab. "Kekerasan dalam Rumah Tangga: Perspektif Psikologis dan Edukatif." Unisia 61 (2010): p. 247-256. B. Rudi Harnoko. "Dibalik Tindak Kekerasan Terhadap Perempuan." Muwazah vol 2 no 1 (2010): p. 35-45. Puji Astuti. "Kemandirian dan Kekerasan Terhadap Istri." Buletin Psikologi 10, no. 2 (2002). Nurul Huda, "Kekerasan Terhadap Anak dan Masalah Sosial yang Kronis." Pena Justisia Jurnal Media Komunikasi dan Kajian Hukum 7, no. 14 (2008). Bhennita Sukmawati. "Hubungan Tingkat Kepuasan Pernikahan Istri dan Coping Strategy dengan Kekerasan dalam Rumah Tangga." Jurnal Sains dan Praktik Psikologi 2, no. 3 (2014): p. 205-218. Erni Sulastri, dan Sofia Retnowati. "Study Eksploratif Tentang Kekerasan Terhadap Perempuan dalam Rumah Tangga di Kabupaten Indramayu Jawa Barat.” Psikologika: Jurnal Pemikiran dan Penelitian Psikologi 8, no. 16 (2003): p. 30-40. Siti Rohmah Nurhayati. "Peningkatan Kemampuan Menggunakan Problem Focused Coping Perempuan Korban Kekerasan dalam Rumah Tangga." Humanitas: Indonesian Psychological Journal 3, (2006): p. 18-2. 
violence). Perpetrators and victims in domestic violence can happen to anyone, not limited by strata, social status, education level, and ethnicity.

Violence against wives in households is a serious social problem, but there is less response from the public and law enforcement officials for several reasons. First, the absence of accurate crime statistics. Second, the violence against wives in household scope is very private and secure privacy with regard to purity and harmony of the household. Third, the violence against wives is considered reasonable because the right of the husband as leader and head of the family. Fourth, the violence against wives in households occurred due to people view of marriage as an official relationship. ${ }^{3}$

Whereas, the mandate of the UN Special Rapporteur on Violence against Women (SRVAW) has defined violence in the family as: 'violence perpetrated in the domestic sphere which targets women because of their role within that sphere or as violence which is intended to impact, directly and negatively, on women within the domestic sphere. From this definition it becomes clear that violence in the family encompasses much more than woman-battering. ${ }^{4}$

${ }^{3}$ Elli N Hasbianto, Domestic Violence. Grim Portrait of Life of Women in Marriages, Paper Presented at the National Seminar on the Protection of Women from Harassment and Sexual Violence. UGM, 6 November 1996. See also Hamidah Abdurrachman, "Perlindungan Hukum Terhadap Korban Kekerasan dalam Rumah Tangga dalam Putusan Pengadilan Negeri Sebagai Implementasi Hak-hak Korban", Jurnal Hukum 17, No. 3, (Juli 2010): p. 475 - 491. Dwi Wachidiyah Ningsih, "Penganiayaan Secara Psikis dalam Rumah Tangga Berdasarkan Undang-Undang Nomor 23 Tahun 2004 Tentang Kekerasan dalam Rumah Tangga", Jurnal Ilmiah Cahaya Kampus 13, No 2, Universitas Gresik, (Desember 2015): p. 1-21. Bambang Hartono. "Bentuk Perlindungan Hukum Terhadap Perempuan Pelapor Selaku Saksi Korban Kekerasan dalam Rumah Tangga." Keadilan Progresif 5, no. 1 (2014). Jean Abbott, Robin Johnson, Jane Koziol-McLain, and Steven R. Lowenstein. "Domestic Violence Against Women: Incidence and Prevalence in an Emergency Department Population." Jama 273, no. 22 (1995): p. 1763-1767. Johnson, Michael P., and Kathleen J. Ferraro. "Research on Domestic Violence in the 1990s: Making Distinctions." Journal of Marriage and Family 62, no. 4 (2000): p. 948-963. Katherine M. Kitzmann, Noni K. Gaylord, Aimee R. Holt, and Erin D. Kenny. "Child Witnesses to Domestic Violence: A Meta-Analytic Review." Journal of consulting and clinical psychology 71, no. 2 (2003): p. 339. Julia C. Babcock, Charles E. Green, and Chet Robie. "Does Batterers' Treatment Work? A Meta-Analytic Review of Domestic Violence Treatment." Clinical Psychology Review 23, no. 8 (2004): p. 1023-1053. Jeffrey L Edleson. "Children's Witnessing of Adult Domestic Violence." Journal of Interpersonal Violence 14, no. 8 (1999): p. 839-870.

${ }^{4}$ Ingrid Westendorp, "Domestic Violence and The Way Forward" Mimbar Hukum 22, Nomor 2, (Juni 2010): p. 206. John Fantuzzo, Robert Boruch, Abdullahi Beriama, Marc Atkins, 
The issue of domestic violence is one of the phenomena of various kinds of violence case today. As with other cases of violence continue to rise, domestic violence from year to year also increases. The phenomenon of violence against family members can happen anytime, anywhere, and under any circumstances. This violence includes physical and non-physical violence, sexual violence and the economy.

On 22 September 2004, the Government of Indonesia issued a regulation of Law No. 23 of 2004 on the Elimination of domestic violence (PDKRT Law). Although the legislation has been ten (10) years, however many still do not understand about it. This law was enacted to meet the demands of society, especially of women who makes acts to deal with the domestic violence as part of the law allowing perpetrators punished, and saving the victims as an effort to prevent domestic violence from happening again in Indonesian family.

Besides that, this law was drafted by considering the preamble of the Indonesian law, that every citizen has the right to get a sense of security and freedom from all forms of violence in accordance with the principles of Pancasila (the five basic principles of Indonesia) and with the Constitutions of 1945 that asserted that all forms of violence, especially domestic violence is a violation of human rights and crimes against human dignity as well as forms of discrimination need to be diminished. ${ }^{5}$

and Susan Marcus. "Domestic Violence and Children: Prevalence and Risk in Five Major US Cities." Journal of the American Academy of Child \& Adolescent Psychiatry 36, no. 1 (1997): p. 116-122. Jeanne McCauley, David E. Kern, Ken Kolodner, Laurie Dill, Arthur F. Schroeder, Hallie K. DeChant, Janice Ryden, Eric B. Bass, and Len R. Derogatis. "The "Battering Syndrome": Prevalence and Clinical Characteristics of Domestic Violence in Primary Care Internal Medicine Practices." Annals of Internal Medicine 123, no. 10 (1995): p. 737-746. Michael P Johnson. "Conflict and Control: Gender Symmetry and Asymmetry in Domestic Violence." Violence Against Women 12, no. 11 (2006): p. 1003-1018. Stephanie Holt, Helen Buckley, and Sadhbh Whelan. "The Impact of Exposure to Domestic Violence on Children and Young People: A Review of the Literature." Child Abuse \& Neglect 32, no. 8 (2008): p. 797-810. Natalie J. Sokoloff, and Ida Dupont. "Domestic Violence at the Intersections of Race, Class, and Gender: Challenges and Contributions to Understanding Violence Against Marginalized Women in Diverse Communities." Violence Against Women 11, no. 1 (2005): p. 38-64.

${ }^{5}$ Wahyu Ernaningsih, Perspektif Gender dalam Undang-Undang Kekerasan dalam Rumah Tangga)' eprints.unsri.ac.id / 2177/1. uploaded, April 3, 2018. See also Sabungan Sibarani, "Prospek Penegakan Hukum Undang-Undang Penghapusan Kekerasan dalam Rumah Tangga 
Violence at home (domestic violence), according to Law no 23 of 2004 on the Elimination of Domestic Violence Article 1 states that:

"Any act against someone, especially women, misery or suffer affecting physical, sexual, psychological and or negligence of household including threat to commit acts, coercion, or deprivation of liberty unlawfully within the domestic sphere". ${ }^{6}$

Domestic violence is usually done by those who have full power (powerful). Manfolks have always been a powerful force. In the reality of everyday life, it is manfolks who rules. Thus the wife's position both in domestic life and life outside of the family has become very weak. ${ }^{7}$

Historically, before the advent of legislation of PKDRT, victims of domestic violence against wife, children, or husband is very difficult to find justice or protection on what happened to her. This is not only due to the absence of legal framework, but also due to the majority of Indonesian view that revealing something happens in the household, including violence, is a taboo, shame, and private. So it is hardly ever any incident of domestic violence cases reported to the appropriate authorities or may even expressed to the nearest relatives. Victims prefer to keep silent enjoying the sadness and loneliness in harbored feelings of pain, both physical and psychological.

Islam, as a religion, has been devoted to be perfect until the end of this life, ${ }^{8}$ Based on Qur'an and Sunnah Islam has very high perfectness which includes fundamental aspects about the world and the hereafter, to lead humans in obtaining happiness of this world and hereafter. As the last revealed religion of Allah to His people through last prophet, Islam serves as a mercy and guidance for all people.

(UU PKDRT)", Jurnal Hak Asasi Manusia, Volume 7 No. 1, Juli 2016, p. 1-9.

${ }^{6}$ Rena Yulia, "Restorative Justice Sebagai Alternatif Perlindungan Hukum Terhadap Korban Kekerasan dalam Rumah Tangga”, Jurnal Hukum dan Pembangunan 39, No. 2, (April-Juni 2009): p. 238-254.

7 Mansour Fakih, Analisis Gender dan Transformasi Sosial (Yogyakarta: Pustaka Pelajar, 1999). Compare with Faqiuddin Abdul Kodir, "Kekerasan dalam Rumah Tangga (KDRT) Perspektif Islam: Kompilasi Awal Teks-teks Hadis Rujukan”, Mahkamah: Jurnal Kajian Hukum Islam 1, No. 1, (Juni 2016): p. 14-32.

${ }^{8}$ Haedar Nashir, Gerakan Islam Syariat Reproduksi Salafiyah Ideologis di Indonesia (Jakarta: PSAP Muhammadiyah, 2007), p. 1. See also Assosiasi Komite Bidang Hukum, Himpunan Putusan Hukum Majelis Tarjih Muhammadiyah (Yogyakarta: Muhammadiyah, 2011), p. 278. 
The actualization of the values of Islamic law in legislation aims to identify and understand the benefits of implementation and conceptualization of Islamic law as one part of Indonesian constitution to achieve the national law.

The values of Islamic law are a set of principles of Islamic teachings based on the Qur'an and Sunnah. Their position is interconnected in one unified system, which is intended as the Code of the Conduct as well as a legal basis for the establishment of laws and regulations in Indonesia. The values of Islamic law involves philosophical and transcendental aspect which will manifest itself in the system of norms (system of norms) of Indonesian legislation.

First, the urgency in the constitution of the Constitution-1945 of the Republic of Indonesia, the second, the extent of the actualization of the values of Islamic law in the Law on Elimination of Domestic Violence in Indonesia. The implementation of religious values in particular the legal values in the Act of the Elimination of Domestic Violence in Indonesia can be paid attention in the constitution. Based on the universality of the values of Islamic law, then all legislation products can be used to analyze the Islamic law. However, this study is limited only to the legislation of domestic violence.

The study the elimination of domestic violence is very important. Many cases of domestic violence have occurred in Indonesia, among others are Pasha Ungu case with his wife, Cici Paramida with her husband, Farhat Abbas with his wife, as well as the cases of neglect parenting by both the father and mother.

Meanwhile, on the other hand, the values, principles and rules of Islamic legal norms is sufficient to offer alternative solutions, settlement of social problems faced by Indonesia, but has not been maximized by the policy maker. Therefore connecting both of them is very interesting and progressive to reform national laws in the future. Accordingly, the actualization of these considerations the study of religious values in particular the legal values is the Act about the elimination of domestic violence.

This study aims to analyze and understand the transformation 
of religious values, especially the values of Islamic law in the national regulatory system. It focuses particularly on effort to diminish the domestic violence.

\section{Literature Review}

The study on the transformation of Islamic law values in the legislation of the domestic violence is intended to examine the extent of correlation and consistency of Law No. 12 of 2011 on the Establishment of Regulation Legislation based on Article 28j (2) and Article 31 (5) of the Constitution-1945 of the Republic of Indonesia. The purpose is to identify opportunities in implementing effectively and optimally the values of Islamic law to eliminate domestic violence.

Legal restriction is one of substances of the legislation in Indonesia, which means that the values of religion are included in the implementation of an action or certain legal norms. An act or rule of law should be subject to the restrictions established by law to meet the demands which are appropriate consideration of the religious values. The transformation in this context functions as a means of renewal and reform national laws, especially in the formation of legislation in Indonesia in the field of the elimination of domestic violence. As noted by Roscoe Pound, that "legal function as a means of renewal (a tool of social engineering) and the legal function as an agent of modernization. ${ }^{9}$

The Law about the establishment of regulation as guidance is still under construction on the Indonesian constitution. This means that this law should involve all values and principles contained on the laws.

Study of the transformation of religious values, especially the values of Islamic law in domestic violence in the laws and regulations in Indonesia, is fueled by the Article 28 of the Constitution of the Republic of Indonesia in 1945, and its amendment. Article $28 \mathrm{~g}$ line (1) of the Constitution of 1945 stipulates that "each, the person entitled to the protection of self, family, honor, dignity, and property under his

${ }^{9}$ Abrar Saleng, Kapita Selekta Hukum Sumber Daya Alam (Makassar: Membumi Publishing, 2013), p. 229. 
control, and has the right to feel secured and protected from the threat of fear to do or not do something that is a human right and Article $28 \mathrm{H}$ line (2) of the Constitution of the Republic of Indonesia Year 1945 stipulates that "Everyone is entitled to have the ease and special treatment to obtain the same opportunities and benefits in order to achieve equality and justice." ${ }^{10}$

As one of the protectiion way in Indonesia is that in carrying on the obligations, the people have rights were set by law for the purpose of a religious values.

In addition to the above constitutional considerations, human rights in the Islamic perspective has a special place, and this is because the main purpose of the law (maqashid al-sharia) in Islam which is to defend our religion, mental, moral, property and descent. The violence that occurred in the household in the perspective of Islamic law can be divided into four types:

First, physical abuse. Qur'an and hadith believed by all Muslims as the primary references in all the action. The sources studied and studied in educational institutions and by segments of society, so it is natural if multiple interpretations arise. The Qur'an gives attention to the wife who nushuz in Surah al-Nisa 'verse 34. It asserts that the men are in charge of women, because Allah has preferred some of them (men) on some others (women), and because they (men) spend out of their possessions. So therefore virtuous woman, is obedient to Allah preserve self again when her husband was not there, because God has kept (them) women ye fear rebellion, admonish them and then send them to their beds, and beat them. Then if they obey you, you will not seek a way against them. Allah is Most High, Most Great."

Second, psychological violence. In addition to the physical violence, Islam also pays attention to psychological violence, as in the story of Khaulah, Tha'labah's daughter, who complained to the Prophet as always reviled by her husband, Aus bin Samit. As a devout and obedient wife to

${ }^{10}$ Roeslan Saleh, Penjabaran Pancasila dan UUD 45 dalam Perundang-undangan (Jakarta: Pustaka Aksara, 1979), p. 32. 
her husbands, Khaulah remains patient even if she was verbally offended. One day, however, she lose the patience for her husband, because he was mad just because no available food at home. The following night Khaulah rejects her husband. This event brought to the Prophet and then surah al-Mujadalah about zhīhar line 1-6 came down which implies that her husband may not be easy to zhihar his wife. ${ }^{11}$

Third, sexual violence, violence in question is forced sexual activity by one party against another party, called marital rape. In this case the question of violence is violence committed by husbands against wives. Thus marital rape is violence or coercion committed by a husband against his wife for sexual activity without consideration of conditions. ${ }^{12}$

Fourth, economic violence that is if the husband does not provide a living, care or maintenance in accordance with applicable law or agreement between the husband and wife. This kind of violence includes neglecting, restricting or prohibiting someone to work properly inside or outside the home. Islam states clearly not tolerate neglect and violence in terms of economy.

From the explanation above it is clear that Islam totally prohibits acts of domestic violence as well as neglect of children.

\section{Discussion}

In the Constitution of the Republic of Indonesia 1945 especially in article $28 \mathrm{~g}$ line (1) and Article $28 \mathrm{H}$ line (2), it appears that the

${ }^{11}$ Siti Zumrotun, Membongkar Fiqh Patriarkhis: Refleksi atas Keterbelengguan Perempuan dalam Rumah Tangga (STAIN Press, 2006), p. 111. Compare Ipandang. "Fiqh Perempuan, Kekinian dan Keindonesiaan (Telaah Kritis Membangun Fiqh Berkeadilan Gender)." Al-Maiyyah 8, no. 1 (2015): p. 79-98. Tutik Hamidah. "Akar Kekerasan Terhadap Perempuan dalam Fiqh Al-Nisa'." El-Harakah (Terakreditasi) 3, no. 1 (2008): p. 59-66. Yayuk Fauziyah. "Ulama Perempuan dan Dekonstruksi Fikih Patriarkis." ISLAMICA: Jurnal Studi Keislaman 5, no. 1 (2010): p. 161-174. Neng Hannah. "Seksualitas dalam Alquran, Hadis dan Fikih: Mengimbangi Wacana Patriarki." Wawasan: Jurnal Ilmiah Agama dan Sosial Budaya 2, no. 1 (2017): p. 45-60.

${ }^{12}$ Milda Marlia, Marital Rape: Kekerasan Seksual Terhadap Istri (Yogyakarta: PT. LKiS Pelangi Aksara, 2007), p. 11. See also also Ronald Varit Sabaja, "Flora Pricilla Kalalo, Theodorus H. W. Lumunon, "Perlindungan Hukum Terhadap Korban Kekerasan dalam Rumah Tangga (KDRT) (Studi Kasus di Wilayah Hukum Polresta Manado), Lex Et Societatis 6, No. 3, (Mei 2018): p. 5-13. 
presence of religious values is important. Thus the values of Islamic law as part of Islamic values become indicators of a rule of constitutional or unconstitutional by the Constitution 1945 .

Therefore, provisions Article $28 \mathrm{~g}$ line (1) and Article $28 \mathrm{H}$ line (2) of the Constitution of the Republic of Indonesia of 1945 became the legal basis for consideration of the establishment of the laws on the elimination of domestic violence. Then in the preparation of legal principles and substance, the legislation should spell out explicitly any of religious values.

This analysis is important because the determination of the principles or the principles in constitution always have relevance to the values used. So that, the principles used are not out of the existing value.

Furthermore, as the principles are translated into norms or rules, the regulations will look consistent in its implementation of the religious values as stated in article $28 \mathrm{~g}$ line (1) and Article $28 \mathrm{H}$ line (2) of the Constitution-1945 of the Republic of Indonesia. ${ }^{13}$ If the provision of religious values are concretely translated in the material law, it can be said that the Constitution-1945 of the Republic of Indonesia is religious. The study of the values of Islamic law in the legislation, including the actualization of the values of Islamic law can be analyzed through the Law of the Republic of Indonesia Number 23 of 2004 on the Elimination of Domestic Violence, as well as the Article no. $28 \mathrm{~g}$ line (1) and Article $28 \mathrm{H}$ line (2) of the Constitution-1945 of the Republic of Indonesia. In the two regulation, religious values serves as a guidance in regulating husband's right upon his wife.

The values of Islam which can be transformed into the Law of Domestic Violence Elimination are:

\section{1) Principle of Respect for Human Rights}

The first principle in Act No. 23 of 2004 on the Elimination of Domestic Violence is the principle of respect for human rights. The

${ }^{13}$ Undang-Undang Dasar Republik Indonesia 1945 (Jakarta: Sinar Grafika, 2011), p. 10. 
discussion is set forth here in order to see the transformation of Islamic law principles.

The teaching of Islam on human rights shows that Islam as a religion has placed man as honorable and noble creature. Therefore, the protection and respect for the human being must be carried out by human beings.

Human rights (HAM) in Islam has been discussed since fourteen years ago. This is evidenced by the Charter of Medina (mitsaq al-Madinah) That occurs at the time of the Prophet Muhammad emigrated to Madinah. In Madina or Medina Charter document that contains among others the recognition and affirmation that all groups in the city of the Prophet, namely Jewish, Christian and Muslim, are a single nation. In recognition of all parties to work together as a nation, there is a recognition within the charter on human rights issues for each party to the agreement on the charter. Therefore, we can see that in the charter of Madina human rights are already adopted by Islam. The theme of human rights in Islam is actually the theme that always arises in the long history of human being, especially in the modern era.

\section{2) Principle of Justice and Gender Equality}

The second principle in the Act No. 23 of 2004 on the Elimination of Domestic Violence is the principles of fairness and gender equality. The real meaning of the elimination of domestic violence in this law is to prevent all forms of domestic violence (preventive goals), protect victims of domestic violence (protective goals), act against perpetrators of domestic violence (repressive goals), and maintain integrity harmonious and prosperous household (consolidative purpose) which is the realization of the principle of equal rights and respect for human dignity. ${ }^{14}$ Islamic perspective on justice and gender equality presented here in an effort to see Islamic law in the transformation of this principle.

Islam brought justice, equality and the idea of equality among all

${ }^{14}$ Ridwan Mansyur, "Tindak Pidana Kekerasan dalam Rumah Tangga Menurut Sistem Peradilan Pidana dalam Perspektif Restorative Justice Perspective", Jurnal Hukum dan Peradilan 5, No. 3, (November 2016): p. 433. 
human beings. Islam also put women at a respectable position, in which the position of women ignorant society is very low.

\section{3) Non-discrimination}

The third principle in the Act No. 23 of 2004 on the Elimination of Domestic Violence is the principle of non-discrimination. Islamic perspective regarding the nondiscrimination principle mentioned here.

Islam is a religion that eliminates all forms of discrimination, whether discrimination based on ethnicity, race, religion, color, sex and so on. Allah sent the Prophet to carry out social change by declaring equality and justice for all mankind (see Q.s. al-Hadid: 25, al-Araf: 157 and al-Nisa: 5)

\section{4) Victims Protection}

The fourth principle in the Act No. 23 of 2004 on the Elimination of Domestic Violence is the principle of the protection of victims.

In the Islamic criminal law, the protection of victims is aimed at fulfilling the victim rights. Thus the victim has the rights to seek that the perpetrator to be punished in accordance with what he did against the victims, either qishâs, hudûd, diyât or ta'zîr. Victims of violence will be given great rights and determine the case through the court (making up).

Every human being, including the victim is protected by Islam (Quran and Sunnah) and therefore if it is violated, the injured party (victims of violence / crime) were given the right (authority) against those who cause harm (actor). In addition, victims receive protection from the authorities, which includes a guarantee of safety, health and others.

The purposes of Domestic Violence Elimination are: to prevent all forms of domestic violence, to protect victims of violence, to prosecute the doers, as well as to maintain the integrity of the household. In Islamic law, the discussion regarding conjugal relations is on the understanding that a marriage should be undertaken with a peaceful mood, balance of rights and obligations between husband and wife. No other goal of marriage except to make the family sakinah, mawaddah and full of mercy. 
In addition, in detailed criminal provisions, namely article 44 to article 50. It determines one or two sentence with the lowest and highest limits so that judges are limited in determining his sentence. In Islamic law, the nature of crime is elastic so as to encompass all such events in qishâs and diyât. The judge did not create himself in hand, qishâs and diyât.

Material relating to violence Article 5 (a) is "Every person is prohibited from doing violence within the scope of the household by means of physical violence, psychological violence, sexual abuse, or neglect of household. (B) In the event that the principle used to Law No. 23 of 2004 to the principle of respect for human dignity, as well as antiviolence or discrimination and also the principle of protection of the victim. Islamic law describes pattern of husband-wife relations based on mu'asyarah bil ma'rûf, and forbids commit violence either against the wife or the husband in favor of the exemption in establishing a balance between the values of humanity.

Based on the above desciption, it is understood that Islamic Law and the Law on Elimination of Domestic Violence have the same spirit in the matter of violences in the domestic sphere, namely respect for human dignity, to do with the rights of spouses in the household, as well as anti-violence or discrimination against women.

But it is difference in terms of the provisions of the criminal, the Law on the Elimination of Domestic Violence already provides for punishment for the perpetrators of violence, whereas Islamic law does not penal provisions for those who commit violence against wives in households, but puts forward the concept of marriage is Sakinah, mawadah, warahmah. It is clear that violence against wives in household according to the Law on the Elimination of Domestic Violence and Islamic law is not allowed.

\section{Conclusion}

Based on the description above, visible transformation efforts to actualize religious values on the articles of the Law on the Elimination of Domestic Violence in Indonesia is necessary. Despite the fact that Indonesian law is still not fully actualized Islam in the implementation of Indonesian constitution and law. 


\section{Bibliography}

Abdurrachman, Hamidah. "Perlindungan Hukum Terhadap Korban Kekerasan dalam Rumah Tangga dalam Putusan Pengadilan Negeri Sebagai Implementasi Hak-Hak Korban.” Jurnal Hukum Ius Quia Iustum 17, no. 3 (2010): 475-491.

Abdul Kodir, Faqiuddin. "Kekerasan dalam Rumah Tangga (KDRT) Perspektif Islam: Kompilasi Awal Teks-teks Hadis Rujukan”, Mahkamah: Jurnal Kajian Hukum Islam 1, No. 1, (Juni 2016): 14-32.

Astuti, Puji. "Kemandirian dan Kekerasan Terhadap Istri." Buletin Psikologi 10, no. 2 (2002).

Assosiasi Komite Bidang Hukum. Himpunan Putusan Hukum Majelis Tarjih Muhammadiyah. Yogyakarta: Muhammadiyah, 2011.

Ernaningsih, Wahyu. Perspektif Gender dalam Undang-Undang Kekerasan dalam Rumah Tangga)' eprints.unsri.ac.id / 2177/1. Uploaded dated 3 April 2018.

Fanani, Estu Rakhmi. "Undang-Undang Nomor 23 Tahun 2004 Tentang Kekerasan dalam Rumah Tangga, Antara Terobosan Hukum dan Fakta Pelaksanaannya", Jurnal Legislasi Indonesia 5, No. 3, (September 2008): 2-171.

Fakih, Mansour. Menggeser Konsepsi Gender dan Transformasi Sosial. Yogyakarta: Pustaka Pelajar, 1996. . Analisis Gender dan Transformasi Sosial. Yogyakarta: Pustaka Pelajar, 1999.

Fantuzzo, John, Robert Boruch, Abdullahi Beriama, Marc Atkins, and Susan Marcus. "Domestic Violence and Children: Prevalence and Risk in Five Major US Cities." Journal of the American Academy of Child \& Adolescent Psychiatry 36, no. 1 (1997): 116-122.

Fauziyah, Yayuk. "Ulama Perempuan dan Dekonstruksi Fikih Patriarkis." ISLAMICA: Jurnal Studi Keislaman 5, no. 1 (2010): 161-174. Harnoko, B. Rudi. "Dibalik Tindak Kekerasan Terhadap Perempuan." Muwazah 2, no 1 (2010): 35-45.

Hannah, Neng. "Seksualitas dalam Alquran, Hadis dan Fikih: Mengimbangi Wacana Patriarki." Wawasan: Jurnal Ilmiah Agama dan Sosial Budaya 2, no. 1 (2017): 45-60. 
Hamidah, Tutik. "Akar Kekerasan Terhadap Perempuan dalam Fiqh alNisa'." El-Harakah (Terakreditasi) 3, no. 1 (2008): 59-66.

Holt, Stephanie, Helen Buckley, and Sadhbh Whelan. "The Impact of Exposure to Domestic Violence on Children and Young People: A Review of the Literature." Child Abuse \& Neglect 32, no. 8 (2008): 797-810.

Huda, Nurul. "Kekerasan Terhadap Anak dan Masalah Sosial yang Kronis." Pena Justisia Jurnal Media Komunikasi dan Kajian Hukum 7 , no. 14 (2008).

Ipandang. "Fiqh Perempuan, Kekinian dan Keindonesiaan (Telaah Kritis Membangun Fiqh Berkeadilan Gender)." Al-Maiyyah 8, no. 1 (2015): 79-98.

Mansyur, Ridwan. "Tindak Pidana Kekerasan dalam Rumah Tangga Menurut Sistem Peradilan Pidana dalam Perspektif Restorative Justice Perspective", Jurnal Hukum dan Peradilan 5, No. 3, (November 2016): 433

Marlia, Milda. Marital Rape: Kekerasan Seksual Terhadap Istri. Yogyakarta: PT. LKiS Pelangi Aksara, 2007.

McCauley, Jeanne, David E. Kern, Ken Kolodner, Laurie Dill, Arthur F. Schroeder, Hallie K. DeChant, Janice Ryden, Eric B. Bass, and Len R. Derogatis. "The "Battering Syndrome": Prevalence and Clinical Characteristics of Domestic Violence in Primary Care Internal Medicine Practices." Annals of Internal Medicine 123, no. 10 (1995): 737-746.

Nashir, Haedar. Gerakan Islam Syariat Reproduksi Salafyah Ideologis di Indonesia. Jakarta: PSAP Muhammadiyah, 2007.

Nurhayati, Siti Rohmah. "Peningkatan Kemampuan Menggunakan Problem Focused Coping Perempuan Korban Kekerasan dalam Rumah Tangga." Humanitas: Indonesian Psychological Journal 3, (2006): 18-2 P Johnson, Michael. "Conflict and Control: Gender Symmetry and Asymmetry in Domestic Violence." Violence Against Women 12, no. 11 (2006): 1003-1018.

Rofiq, Ahmad. Hukum Islam di Indonesia. Jakarta: RajaGrafindo Persada, 1998. 
Sukmawati, Bhennita. "Hubungan Tingkat Kepuasan Pernikahan Istri dan Coping Strategy dengan Kekerasan dalam Rumah Tangga." Jurnal Sains dan Praktik Psikologi 2, no. 3 (2014): 205-218.

Sulastri, Erni, dan Sofia Retnowati. "Study Eksploratif Tentang Kekerasan Terhadap Perempuan dalam Rumah Tangga di Kabupaten Indramayu Jawa Barat." Psikologika: Jurnal Pemikiran dan Penelitian Psikologi 8, no. 16 (2003): 30-40.

Sokoloff, Natalie J., and Ida Dupont. "Domestic Violence at the Intersections of Race, Class, and Gender: Challenges and Contributions to Understanding Violence Against Marginalized Women in Diverse Communities." Violence Against Women 11, no. 1 (2005): 38-64.

Saleng, Abrar. Capita Selecta Hukum Sumber Daya Alam. Makassar: Membumi Publishing, 2013.

Saleh, Roeslan. Penjabaran Pancasila dan UUD 45 dalam Perundangundangan. Jakarta: Pustaka Aksara, 1979.

Sibarani, Sabungan. "Prospek Penegakan Hukum Undang-Undang Penghapusan Kekerasan dalam Rumah Tangga (UU PKDRT)”, Jurnal Hak Asasi Manusia, Volume 7 No. 1, (Juli 2016), 1-9.

Undang-Undang Republik Indonesia 1945. Jakarta: Sinar Grafika, 2011. Varit Sabaja, Ronald. "Flora Pricilla Kalalo, Theodorus H. W. Lumunon, "Perlindungan Hukum Terhadap Korban Kekerasan dalam Rumah Tangga (KDRT) (Studi Kasus di Wilayah Hukum Polresta Manado), Lex Et Societatis 6, No. 3, (Mei 2018): 5-13.

Wahab, Rochmat. "Kekerasan dalam Rumah Tangga: Perspektif Psikologis dan Edukatif." Unisia 61 (2010): 247-256.

Westendorp, Ingrid. "Domestic Violence and The Way Forward” Mimbar Hukum 22, Nomor 2, (Juni 2010): 206.

Yulia, Rena. "Restorative Justice Sebagai Alternatif Perlindungan Hukum Terhadap Korban Kekerasan dalam Rumah Tangga”, Jurnal Hukum dan Pembangunan 39, No. 2, (April-Juni 2009): 238-254.

Zumrotun, Siti. Membongkar Figh Patriarkhis: Refleksi atas Keterbelengguan Perempuan dalam Rumah Tangga. Salatiga: STAIN Salatiga Press, 2006. 